University of Wollongong

Research Online

Australian Institute for Innovative Materials -

Papers

Australian Institute for Innovative Materials

$1-1-2018$

Towards thermally stable high performance lithium-ion batteries: the combination of a phosphonium cation ionic liquid and a 3D porous molybdenum disulfide/graphene electrode

Yu Ge

University of Wollongong,yg711@uowmail.edu.au

Cristina Pozo-Gonzalo

Deakin University

Yong Zhao

University of Wollongong, yz705@uowmail.edu.au

Xiaoteng Jia

University of Wollongong, xj916@uowmail.edu.au

Robert L. Kerr

Deakin University

See next page for additional authors

Follow this and additional works at: https://ro.uow.edu.au/aiimpapers

Part of the Engineering Commons, and the Physical Sciences and Mathematics Commons

Research Online is the open access institutional repository for the University of Wollongong. For further information contact the UOW Library: research-pubs@uow.edu.au 


\title{
Towards thermally stable high performance lithium-ion batteries: the combination of a phosphonium cation ionic liquid and a 3D porous molybdenum disulfide/graphene electrode
}

\author{
Abstract \\ We report a thermally stable high-performance lithium battery using an electrochemically synthesized \\ three-dimensional porous molybdenum disulfide/graphene composite electrode and a phosphonium- \\ based ionic liquid (IL) electrolyte. Benefiting from the structural merits of the chosen electrode and the \\ thermal stability of the electrolyte, the cell coupled with a Li foil exhibits excellent rate performance and \\ cycling capability at room temperature; and that is retained with an even better rate capability at an \\ elevated temperature of $508 \mathrm{C}$. This work may provide a new avenue for the development of safe and high \\ performance lithium-ion batteries at high temperature. \\ Disciplines \\ Engineering | Physical Sciences and Mathematics

\section{Publication Details} \\ Ge, Y., Pozo-Gonzalo, C., Zhao, Y., Jia, X., Kerr, R., Wang, C., Howlett, P. C. \& Wallace, G. G. (2018). Towards \\ thermally stable high performance lithium-ion batteries: the combination of a phosphonium cation ionic \\ liquid and a 3D porous molybdenum disulfide/graphene electrode. Chemical Communications, 54 (42), \\ 5338-5341.

\section{Authors} \\ Yu Ge, Cristina Pozo-Gonzalo, Yong Zhao, Xiaoteng Jia, Robert L. Kerr, Caiyun Wang, Patrick Howlett, and \\ Gordon G. Wallace
}




\section{Journal Name}

\section{COMMUNICATION}

\section{Towards thermally stable high performance lithium-ion batteries: the combination of a phosphonium cation ionic liquid and a 3D porous molybdenum disulfide/graphene electrode}

Received 00th January 20xx, Accepted 00th January 20xx

DOI: $10.1039 / \times 0 \times x 00000 x$

\author{
Yu Ge ${ }^{a}$, Cristina Pozo-Gonzalo ${ }^{b}$, Yong Zhao ${ }^{a}$, Xiaoteng Jia ${ }^{a}$, Robert Kerr ${ }^{b}$, Caiyun Wang*a, Patrick C.
} Howlett*b, and Gordon G. Wallace ${ }^{\mathrm{a}}$

www.rsc.org/

${ }^{14}$ For instance, the IL containing phosphonium with an alkyl ether chain demonstrated an electrochemical window of $4.1 \mathrm{~V}$ and a high $\mathrm{Li}^{+}$transport number of $0.54 ;{ }^{12}$ while that with a small alkyl phosphonium imide demonstrated a high electrochemical window of $5.7 \mathrm{~V}$, a low viscosity of $18.4 \mathrm{mPa}$, and a high conductivity of $13.8 \mathrm{mS} \mathrm{cm}^{-1} .{ }^{13}$ While these features are all highly desirable for LIBs, the use of these electrolytes in lithium-ion batteries has not been reported.

To realize the full potential of an IL electrolyte in a LIB, the electrode must be well-designed with a structure that allows complete wetting and minimizes mass transport losses arising from the higher viscosities. Traditional graphite anodes may not be suitable in this regard because of its low theoretical capacity (372 mAh $\mathrm{g}^{-1}$ ). Molybdenum disulfide $\left(\mathrm{MoS}_{2}\right)$ has emerged as a promising anode candidate owing to its high theoretical capacity $\left(670 \mathrm{mAh} \mathrm{g}{ }^{-1}\right) .{ }^{15}, 16$ Moreover, it can be easily fabricated into various nanostructured composites electrodes to achieve outstanding lithium storage performance. ${ }^{17}$, $18 \mathrm{MoS}_{2}$ nanosheets vertically grown on graphene sheets by the hydrothermal method delivered a large capacity of $1077 \mathrm{mAh} \mathrm{g}^{-1}$ at $100 \mathrm{~mA} \mathrm{~g}^{-1} .{ }^{17} \mathrm{~A}$ free-standing macroporous film composed of chemically exfoliated $\mathrm{MoS}_{2}$ nanosheets and graphene sheets via self-assembly offered a high capacity of $800 \mathrm{mAh} \mathrm{g}^{-1}$ at $100 \mathrm{~mA} \mathrm{~g}^{-1} .{ }^{18}$ Recently we developed an electrochemically synthesized molybdenum sulfide/graphene nanocomposite, which exhibited a very high capacity (over $1200 \mathrm{mAh} \mathrm{g}^{-1}$ at $100 \mathrm{~mA} \mathrm{~g}^{-1}$ ) and excellent rate performance (1016 $\mathrm{mAh} \mathrm{g}^{-1}$ at $\left.2 \mathrm{~A} \mathrm{~g} \mathrm{~g}^{-1}\right){ }^{19}$ The lithium storage performance of these $\mathrm{MoS}_{2}$ /graphene composites in an IL has not been demonstrated.

Here we propose a combination of a small phosphonium cation IL-based electrolyte with a molybdenum sulfide-based electrode for lithium storage applications. The applied electrolyte, a mixture of trimethyl(isobutyl)phosphonium bis(fluorosulfonyl)imide $\quad\left(\mathrm{P}_{11144} \mathrm{FSI}\right)$ and lithium bis(fluorosulfonyl)imide (LiFSI) has demonstrated good performance in lithium batteries with a $\mathrm{LiNi}_{1 / 3} \mathrm{Mn}_{1 / 3} \mathrm{Co}_{1 / 3} \mathrm{O}_{2}$ cathode obtaining a stable capacity of $130 \mathrm{mAh} \mathrm{g}^{-1}$ over 200 cycles at $0.25 \mathrm{~mA} \mathrm{~cm}^{-2} .{ }^{14}$ An electrochemically deposited

\footnotetext{
ARC Centre of Excellence for Electromaterials Science, Intelligent Polymer

Research Institute, AlIM Facility, University of Wollongong, NSW 2522, Australia.

b. Institute for Frontier Materials (IFM), Deakin University, Burwood, Victoria 3125, Australia.

*E-mail:caiyun@uow.edu.au,patrick.howlett@deakin.edu.au

tElectronic Supplementary Information (ESI) available: [details of any supplementary information available should be included here]. See DOI: $10.1039 / \mathrm{x} 0 \times x \times 0000 x$
} 
molybdenum disulfide/graphene composite with a threedimensional porous structure was used as the electrode in this work. The assembled cells exhibited excellent energy storage capacities at room temperature, and a remarkable stability and even better rate capability at higher temperature. This work may provide a good avenue towards practical LIB applications with both high performance and reliability at high temperature.

The chemical structure of $\mathrm{P}_{11144} \mathrm{FSI}$ is depicted in Fig. S1 (ESI + ). The physicochemical properties of $\mathrm{P}_{1114} \mathrm{FSI}$ containing various concentrations of LiFSI $\left(0.5-3.8 \mathrm{~mol} \mathrm{~kg}^{-1}\right)$ have been well studied previously ${ }^{11}$. We used the IL mixture with $3.2 \mathrm{~mol} \mathrm{~kg}^{-1}$ LiFSI in this work because of its favorable physicochemical and $\mathrm{Li}^{+}$transport properties for use in a LIB: no melting and crystallization along with a very low glass transition $(-72.9 \pm 0.2$ $\left.{ }^{\circ} \mathrm{C}\right)$; a reasonable ionic conductivity of $0.9 \pm 0.1 \mathrm{mS} \mathrm{cm}^{-1}$; and a larger $\mathrm{Li}$ transference number $(0.40 \pm 0.01)$ than the conventional $\mathrm{LiPF}_{6} / \mathrm{EC} \mathrm{DEC}$ electrolyte at $25^{\circ} \mathrm{C}(0.24 \pm 0.087) .^{20}$ The electrochemical synthesis of 3D porous $\mathrm{MoS}_{2} /$ graphene was performed in a solution containing $(\mathrm{NH})_{4} \mathrm{MoS}_{4}$, graphene oxide $(\mathrm{GO})$ and $\mathrm{KCl}$. Upon the applied negative potential of -1.2 $\mathrm{V}, \mathrm{GO}$ nanosheets decorated with $\mathrm{MoS}_{4}{ }^{2-}$ migrated and attached onto the stainless steel mesh (SSM) substrate, where $\mathrm{MoS}_{4}{ }^{2-}$ was converted into $\mathrm{MoS}_{2}$ following a reaction of $\mathrm{MoS}_{4}{ }^{2-}$ $+2 \mathrm{e}^{-}+4 \mathrm{H}^{+} \rightarrow \mathrm{MoS}_{2}+2 \mathrm{H}_{2} \mathrm{~S}^{21,22}$ Meanwhile, GO was reduced at such negative potential, ${ }^{23}$ denoting the composite as $\mathrm{MoS}_{2} / \mathrm{rGO}$ thereafter. The random stacking of these sheets created a porous 3D structure.

Scanning electron microscopy (SEM) was applied to characterize the structures. The neat $\mathrm{MoS}_{2}$ film was uniformly coated on the SSM (Fig. 1a) with a compact structure and a thickness of $\sim 640 \mathrm{~nm}$. As revealed by both the cross-sectional view and topographic images, the $\mathrm{MoS}_{2} / \mathrm{rGO}$ electrode displayed a porous three-dimensional (3D) architecture
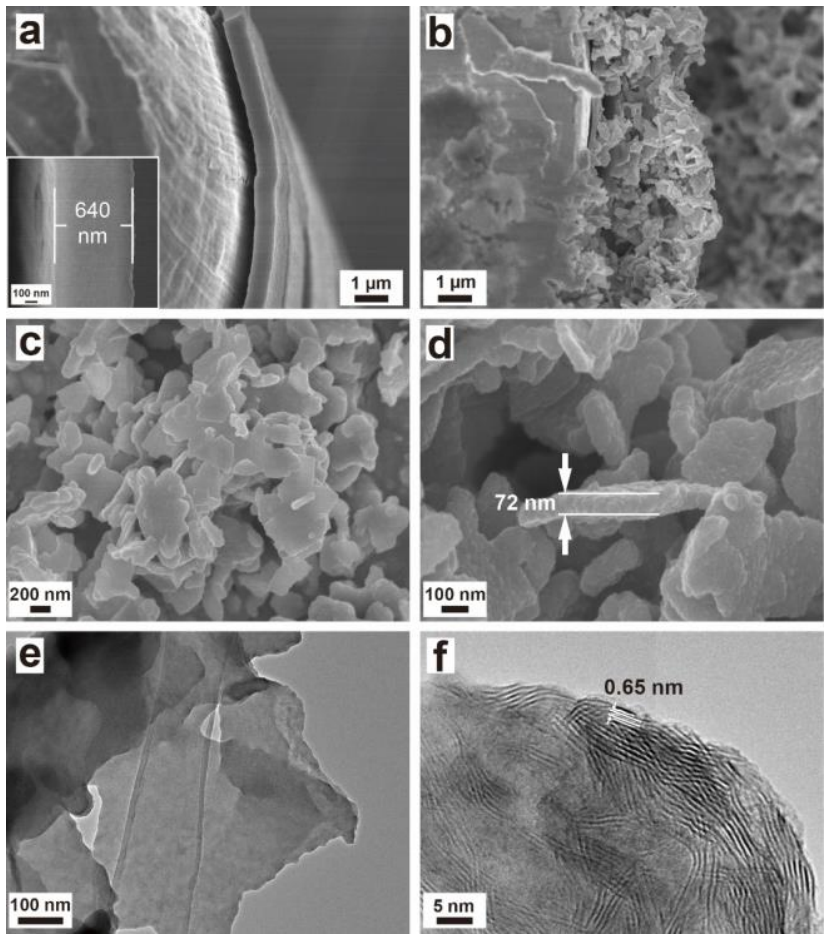

Fig. 1 SEM images of $\operatorname{MoS}_{2}$ (a; inset shows the thickness) and $\mathrm{MoS}_{2} / \mathrm{rGO}(\mathrm{b}-\mathrm{d})$ at different magnifications; (e, f) TEM images of $\mathrm{MoS}_{2} / \mathrm{rGO}$. created by the randomly stacked nanosheets (Fig. $1 \mathrm{~b}$ and c). Such film-like structure showed an average thickness of $\sim 3 \mu \mathrm{m}$, higher than that of the molybdenum sulfide/graphene film deposited by cyclic voltammetry (1-2 $\mu \mathrm{m}$ from 30 cycles). ${ }^{19}$ The lateral size of the composite nanosheets was in a range of several hundred of nanometers with a typical thickness of $\sim 72$ $\mathrm{nm}$. At a higher magnification, the composite sheets displayed a granular surface structure (Fig. 1d). The energy dispersive $X$ ray spectroscopy (EDS) results clearly showed strong Mo and $S$ peaks for both $\mathrm{MoS}_{2}$ and $\mathrm{MoS}_{2} / \mathrm{rGO}$ (Fig. S2a, b, ESI+), while the $C$ peak could only be found in the spectrum of $\mathrm{MoS}_{2} / \mathrm{rGO}$, evidencing the existence of graphene and formation of composite. High-resolution transmission electron microscopy (HRTEM) further evidences that $\mathrm{rGO}$ sheets were evenly coated by $\mathrm{MoS}_{2}$ (Fig. 1e). At a higher magnification, a lattice spacing of $0.65 \mathrm{~nm}$ was shown (Fig. 1f) corresponding to the (002) crystal plane of layered $\mathrm{MoS}_{2}$. These results clearly demonstrate that graphene nanosheets may act as the template and backbone for the growth of $\mathrm{MoS}_{2}$.

The formation of $\mathrm{MoS}_{2}$ was confirmed by Raman, thermogravimetric analysis (TGA) and X-ray photoelectron spectroscopy (XPS). Distinct peaks at 354.6, 410.1 and 458.7 $\mathrm{cm}^{-1}$ were observed in the Raman spectra of neat $\mathrm{MoS}_{2}$ and $\mathrm{MoS}_{2} / \mathrm{rGO}$ (Fig. 2a), which respectively correspond to the $\mathrm{E}^{1}{ }_{2 \mathrm{~g}}$, $\mathrm{A}_{1 \mathrm{~g}}$ and $2 \mathrm{LA}$ modes of hexagonal $\mathrm{MoS}_{2}$ crystal, ${ }^{24}$ confirming the existence of $\mathrm{MoS}_{2}$. For $\mathrm{MoS}_{2} / \mathrm{rGO}$, the $\mathrm{D}$ band and $\mathrm{G}$ band of graphene at $1322 \mathrm{~cm}^{-1}$ and $1601 \mathrm{~cm}^{-1}$ can also be found, evidencing the formation of a composite. TGA curves also provided the evidence of the formation of composite (Fig. S3, ESI + ). These two materials $\mathrm{MoS}_{2}$ and $\mathrm{MoS}_{2} / \mathrm{rGO}$ all displayed a major weight loss at $\sim 400{ }^{\circ} \mathrm{C}$, which can be attributed to the oxidation of $\mathrm{MoS}_{2}$ to $\mathrm{MoO}_{3}$ in air. ${ }^{25}$ An extra weight loss at $\sim 200{ }^{\circ} \mathrm{C}$ was observed for $\mathrm{MoS}_{2} / \mathrm{rGO}$, mainly related to the removal of residual oxygen-containing groups in $\mathrm{rGO} .^{26}$

The formation of molybdenum sulfide can be further shown by the strong Mo and $\mathrm{S}$ peaks in the wide XPS spectrum of $\mathrm{MoS}_{2} / \mathrm{rGO}$ (Fig. 2b), wherein the intensity ratio of S:Mo was calculated to be 1.96 , very close to the stoichiometric number of crystalline $\mathrm{MoS}_{2}$. This ratio is lower than the 2.4 obtained
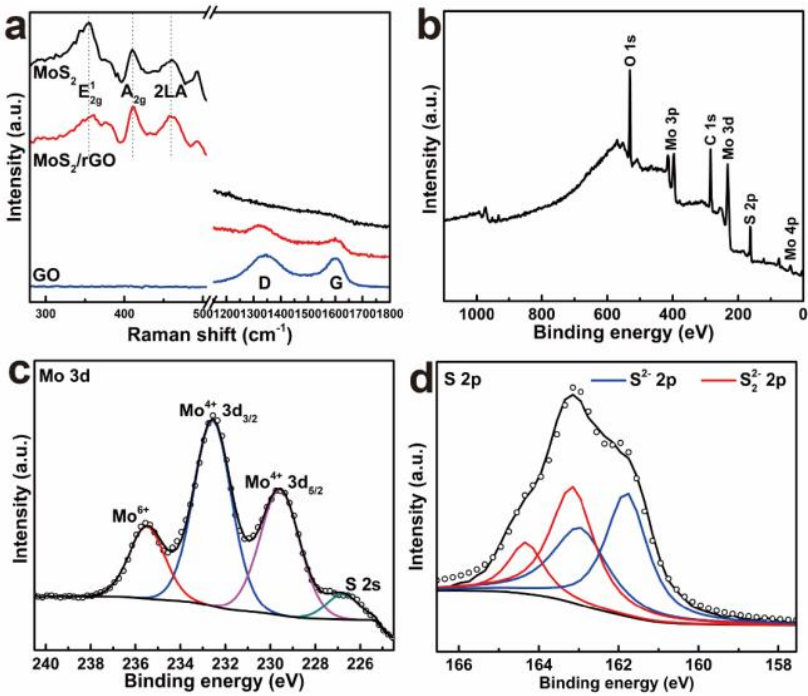

Fig. 2 (a) Raman spectra of $\mathrm{MoS}_{2}, \mathrm{MoS}_{2} / \mathrm{rGO}$ and GO; (b-d) XPS survey spectra Mo 3d spectra and S $2 p$ spectra of $\mathrm{MoS}_{2} / \mathrm{rGO}$. 
for the $\mathrm{MoS}_{\mathrm{x}} / \mathrm{rGO}$ composite synthesized using cyclic voltammetry, since that $\mathrm{MoS}_{3}$ was formed during the anodic process. ${ }^{19}$ In the Mo 3d region, two major peaks at $\sim 229.6 \mathrm{eV}$ and $232.6 \mathrm{eV}$ can be ascribed to Mo $3 \mathrm{~d}_{5 / 2}$ and Mo $3 \mathrm{~d}_{3 / 2}$ binding energies (Fig. 2C), typical for $\mathrm{Mo}^{4+}$ in $\mathrm{MoS}_{2}$. The peak at 235.5 $\mathrm{eV}$ is assigned to $\mathrm{Mo}^{6+}$. In the $\mathrm{S} 2 \mathrm{p}$ region (Fig. $2 \mathrm{~d}$ ), a strong doublet at the lower binding energy ( 161.8 and $163.0 \mathrm{eV})$ represent $S^{2-} 2 p_{3 / 2}$ and $S^{2-} 2 p_{1 / 2}$, characteristic $S 2 p$ peaks of $\mathrm{MoS}_{2}$ crystals. Another weaker doublet at $\sim 163.2$ and $164.3 \mathrm{eV}$ arise from $S_{2}{ }^{2-} 2 p_{3 / 2}$ and $S_{2}{ }^{2-} 2 p_{1 / 2}$, indicating the existence of bridging $\mathrm{S}_{2}{ }^{2-}$ ligands, which constitutes $\mathrm{MoS}_{3}$ in the form of $\mathrm{Mo}^{\mathrm{IV}}\left(\mathrm{S}^{2-}\right)\left(\mathrm{S}_{2}{ }^{2-}\right),{ }^{27}$ suggesting the presence of $\mathrm{MoS}_{3}$ of a minor content. The peaks representing $\mathrm{C}-\mathrm{O}$ and $\mathrm{C}=\mathrm{O}$ at $\sim 285.2 \mathrm{eV}$ and $\sim 287.9 \mathrm{eV}$ decreased dramatically in the $\mathrm{C}$ 1s spectra of $\mathrm{MoS}_{2} / \mathrm{rGO}$ compared to that of GO (Fig. S4a and b, ESIt), proving the massive removal of oxygen-containing groups, namely, reduction of GO.

The electrochemical performance of the cells at room temperature was investigated using cyclic voltammetry (CV) at $0.2 \mathrm{mV} \mathrm{s}^{-1}$ and galvanostatic charge/discharge at $0.1 \mathrm{~A} \mathrm{~g}^{-1}$. By referring to the mass of bare SSM substrate, the areal mass loading of the electrode was about $0.46 \mathrm{mg} \mathrm{cm}^{-2}$ for $\mathrm{MoS}_{2}$ and $0.55 \mathrm{mg} \mathrm{cm}^{-2}$ for $\mathrm{MoS}_{2} / \mathrm{rGO}$. Here, four types of cells were assembled with the combination of two types of electrode $\left(\mathrm{MoS}_{2} ; \mathrm{MoS}_{2} / \mathrm{rGO}\right.$ labelled as MG) and two electrolytes (3.2 mol $\mathrm{kg}^{-1} \mathrm{LiFSI}$ in $\mathrm{P}_{111 i 4} \mathrm{FSI}$, labelled as IL; $1 \mathrm{M} \mathrm{LiPF}_{6}$ in 1:1 ethylene carbonate/dimethyl carbonate, labelled as $(E)$. These cells are denoted as MG-IL, MG-CE, $\mathrm{MoS}_{2}-\mathrm{IL}$, and $\mathrm{MoS}_{2}-\mathrm{CE}$, respectively. The MG-IL cell displayed a sharp cathodic peak at $\sim 0.5 \mathrm{~V}$ in the first CV cycle (Fig. 3a) corresponding to the formation of solid electrolyte interphase (SEI), a main cause for irreversible capacity in the charge/discharge profile (Fig. 3b). ${ }^{17}$ In the following cycles, three cathodic peaks at around $1.82 \mathrm{~V}$, $1.02 \mathrm{~V}$ and $0.41 \mathrm{~V}$ were shown, which can be assigned to the formation of $\mathrm{Li}_{2} \mathrm{~S}$ and $\mathrm{Li}_{x} \mathrm{MoS}_{2}$, decomposition of lithiated $\mathrm{MoS}_{2}$, respectively. ${ }^{28}$ In the anodic process, two major peaks at $\sim 1.56$ and $2.28 \mathrm{~V}$ were shown which arose from the partial oxidation of Mo forming $\mathrm{MoS}_{2}$, and formation of sulfur, respectively. ${ }^{28}$ In the charge/discharge profile, plateaus at $\sim 2.0$ and $1.0 \mathrm{~V}$ in the discharge process, and $\sim 2.2$ and $1.4 \mathrm{~V}$ in the

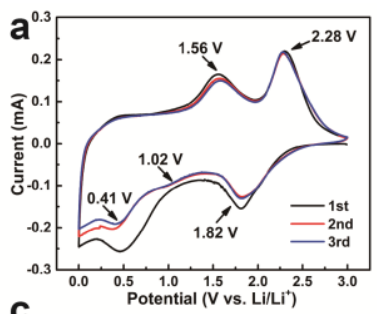

C
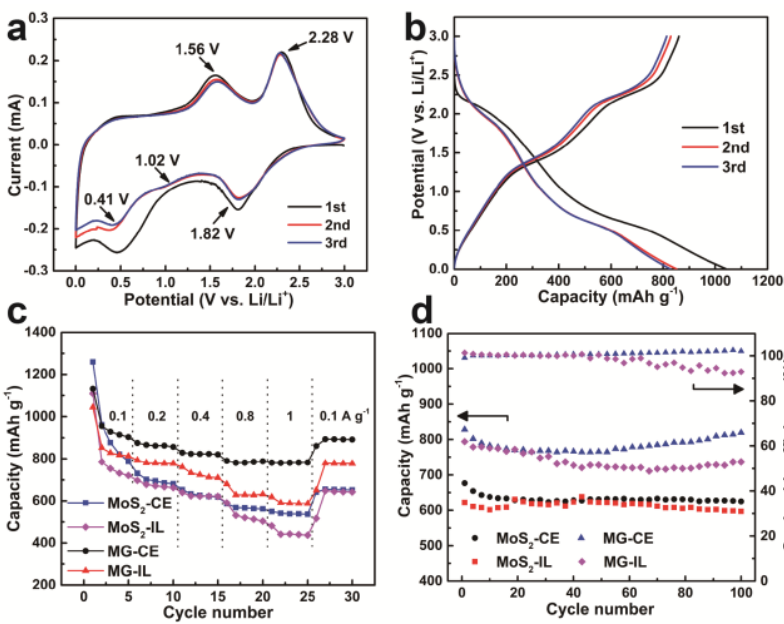

d

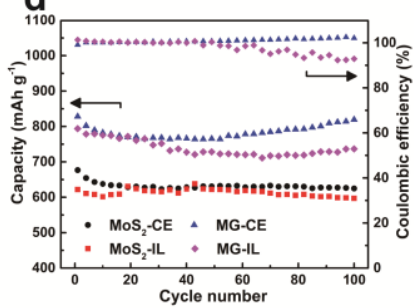

Fig. 3 (a) The first three cyclic voltammograms of the MG-IL cell over a potential range of 0.0-3.0 V vs. Li/Li+ at $0.2 \mathrm{mV} \mathrm{s}^{-1}$; (b) The first three charge/discharge curves of MG-IL at $0.1 \mathrm{~A} \mathrm{~g}^{-1}$; (c) Rate performance of the cells; (d) Cycling performance at $0.4 \mathrm{~A} \mathrm{~g}^{-1}$ of the cells and the Coulombic efficiency of the MG-CE and MG-IL.

This journal is (C) The Royal Society of Chemistry 20xx charge process can be seen; they are the typical Li storage characteristics of $\mathrm{MoS}_{2}$-based materials and are consistent with the CV results. Similar electrochemical behaviours were presented by MG-CE, $\mathrm{MoS}_{2}-\mathrm{CE}$ and $\mathrm{MoS}_{2}$-IL cells as well (Fig. S5, ESI+).

The rate performance of the cells at room temperature was investigated (Fig. 3c). They all delivered a very high specific capacity of 1131, 1044, 1259 and $1109 \mathrm{mAh} \mathrm{g}^{-1}$ during the first cycle for MG-CE, MG-IL, $\mathrm{MoS}_{2}-\mathrm{CE}$ and $\mathrm{MoS}_{2}-\mathrm{IL}$, respectively. The MG-CE exhibited the highest reversible capacities at all current densities investigated (0.1-1 $\left.\mathrm{A} \mathrm{g}^{-1}\right)$ : 955, 875, 829, 790 and $782 \mathrm{mAh} \mathrm{g}^{-1}$ for $0.1,0.2,0.4,0.8$ and $1 \mathrm{~A} \mathrm{~g}^{-1}$-applied current. The MG-IL offered a comparable capacity of 852,793 and $761 \mathrm{mAh} \mathrm{g}^{-1}$ at a current density of $0.1,0.2$ and $0.4 \mathrm{~A} \mathrm{~g}^{-1}$; a lower capacity of 629 and $590 \mathrm{mAh} \mathrm{g}^{-1}$ at 0.8 and $1 \mathrm{~A} \mathrm{~g}^{-1}$. This is attributed to the higher viscosity and lower conductivity of the IL electrolyte. The rate capability of both MG cells is superior to those obtained using $\mathrm{MoS}_{2}$, confirming advantages accrued using the 3D porous structure over that of a compact nature. It can be attributed to the following aspects: high conductivity of the rGO matrix improving the electron transport; enlarged electrolyte- electrode interface which facilitates greater $\mathrm{Li}^{+}$ diffusion into the electrode structure. Importantly, the capacity delivered from the MG-IL cell is much higher than that of the graphite anode in FSI-based IL electrolyte (360 mAh g-1 at 0.2 C). ${ }^{29}$

The cycling performance at room temperature was studied at a current density of $0.4 \mathrm{~A} \mathrm{~g}^{-1}$ (Fig. 3d). All systems investigated displayed good cycling stability over 100 charge/discharge cycles, and the MG-CE showed the best cycling performance of an initial reversible capacity of $828 \mathrm{mAh} \mathrm{g}^{-1}$ and $819 \mathrm{mAh} \mathrm{g}^{-1}$ at the 100th cycle, a retention rate of $99 \%$ with a stable Coulombic efficiency close to $100 \%$. The MG-IL delivered an initial reversible capacity of $794 \mathrm{mAh} \mathrm{g}^{-1}$ and $737 \mathrm{mAh} \mathrm{g}^{-1}$ at the 100th cycle with a retention rate of $93 \%$ and a Coulombic efficiency of $94 \%$, which is inferior to the MG-CE cell. Nevertheless, this cycling stability is better than those of reported $\mathrm{MoS}_{2} /$ graphene composites with conventional solvent-based electrolyte, including hydrothermally synthesized composites (a retention rate of $88.6 \%$ over 100 cycles at $\left.100 \mathrm{~mA} \mathrm{~g}^{-1}\right)^{30}$ and exfoliated $\mathrm{MoS}_{2}$ nanosheets hybrid with graphene $\left(71 \%\right.$ retained over 100 cycles at $\left.100 \mathrm{~mA} \mathrm{~g}^{-1}\right) .^{31}$ These cells were further characterized by electrochemical impedance spectra (EIS). The Nyquist plots with a suppressed semi-circle at high-frequency region and a linear part at lowfrequency region were fitted using an equivalent circuit model composed of $R_{s}, R_{c t}, C P E$ and $Z_{W}$, representing contact resistance, charge transfer resistance, constant phase element, and Warburg impedance, respectively. It is noticeable that the MG-IL showed a lower $R_{c t}(32 \Omega)$ than that of the MG-CE (87 $\Omega$ )
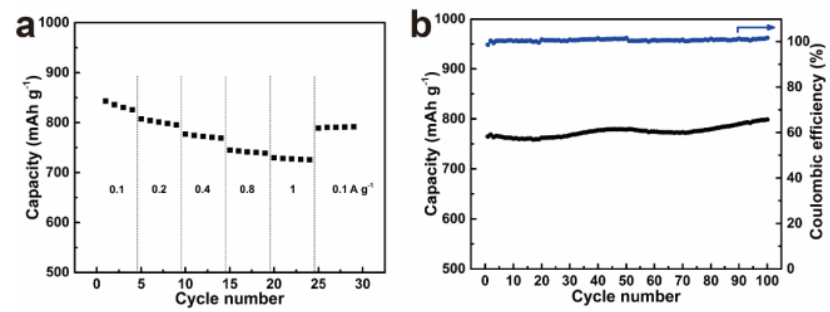

Fig. 4 Rate capability (a) and cycling performance at $0.4 \mathrm{~A} \mathrm{~g}^{-1}$ (b) of MG-IL recorded at $50^{\circ} \mathrm{C}$

J. Name., 2013, 00, 1-3 | 3 
(Fig. S6a, ESIt). This may be attributed to the high concentration of LiFSI in the IL electrolyte, leading to an increased $\mathrm{Li}^{+}$transference number. ${ }^{11}$ Both $\mathrm{MoS}_{2}-\mathrm{CE}$ and $\mathrm{MoS}_{2-}$ IL exhibited a larger $R_{c t}$ of 115 and $151 \Omega$ (Fig. S6b, ESI + ), which we expect is due to their compact film structure.

The charge/discharge performance of MG-IL at a high temperature $\left(50^{\circ} \mathrm{C}\right)$ was investigated with the MG-CE cells as controls. However, most of the MG-CE cells failed even at the first cycle, and no sufficient results could be collected. This may be ascribed to the poor thermal stability of organic solvent and the possible decomposition of $\mathrm{LiPF}_{6}$ salt at $50{ }^{\circ} \mathrm{C}$. In contrast, the MG-IL cell displayed excellent rate performance (Fig. 4a), a reversible capacity of $843,804,774$, 743 and $728 \mathrm{mAh} \mathrm{g}^{-1}$ was delivered at $0.1,0.2,0.4,0.8$ and $1 \mathrm{~A}$ $\mathrm{g}^{-1}$, respectively. The capacities at lower current densities (0.1$0.4 \mathrm{~A} \mathrm{~g}^{-1}$ ) are very close to those recorded at room temperature, yet there is a $20 \%$ increase in the capacities delivered at 0.8 and $1 \mathrm{~A} \mathrm{~g}^{-1}$. It indicates that the ionic liquid electrolyte not just withstands the high temperature owing to its outstanding thermal stability, but also benefits from the resultant lowered viscosity and improved ionic conductivity. ${ }^{10}$ The MG-IL showed an excellent cycling performance over 100 cycles at $0.4 \mathrm{~A} \mathrm{~g} \mathrm{~g}^{-1}$ : the capacity did not drop but slightly ascended (Fig. 4b). Also, the Coulombic efficiency was kept at $\sim 100 \%$ for all the cycles. The slight increase of the capacity over the cycling may be due to the slow wetting of the electrode by electrolyte. All these results suggest the potential use of $\mathrm{P}_{11144} \mathrm{FSI}$ IL electrolyte in LIBs to simultaneously ensure safety and retain high performance at high temperature.

In summary, the electrodeposited $\mathrm{MoS}_{2} / \mathrm{rGO}$ composite as an electrode exhibited high capacities, good rate capability and good cycling stability when using $\mathrm{P}_{111 i 4} \mathrm{FSI}$ ionic liquid-based electrolyte for lithium storage. The graphene-backboned 3D architecture provided an enhanced electrode/electrolyte interface, which facilitates easy access of IL electrolyte with high viscosity. Importantly, this type of cell demonstrated an outstanding cycling and rate performance at a high temperature of $50{ }^{\circ} \mathrm{C}$ owing to the thermal properties of IL. This work may provide a solution for fabricating highperformance and safe lithium-ion batteries at high temperatures. This concept can also be expanded to other electrochemical energy storage/conversion applications that involve the utilization of electrolyte-electrode interface such as sodium ion batteries, supercapacitors and electrocatalysis.

Dedicated to Professor Jin-Pei Cheng on the occasion of his 70th birthday. Funding from the Australian Research Council Centre of Excellence Scheme (CE 140100012) is gratefully acknowledged. G.G.W. is grateful to the ARC for support under the Australian Laureate Fellowship scheme (FL110100196). The authors thank the Australian National Fabrication FacilityMaterials node (ANFF) and the UOW Electron Microscopy Centre for equipment use.

\section{Conflicts of interest}

There are no conflicts to declare.

\section{Notes and references}

1 B. Scrosati, Nature, 2011, 473, 448.

2 J. B. Goodenough and K.-S. Park, J. Am. Chem. Soc., 2013, 135, 1167-1176.

3 S.-K. Kim, H.J. Kim, J.-C. Lee, P.V. Braun, H.S. Park, ACS Nano, 2015, 9 8569-8577.

4 J. B. Goodenough, Acc. Chem. Res., 2013, 46, 1053-1061.

5 D. R. MacFarlane, N. Tachikawa, M. Forsyth, J. M. Pringle, P. C. Howlett, G. D. Elliott, J. H. Davis, M. Watanabe, P. Simon and C. A. Angell, Energy Environ. Sci., 2014, 7, 232-250.

6 M. Armand, F. Endres, D. R. MacFarlane, H. Ohno and B. Scrosati, Nat. Mater., 2009, 8, 621-629.

7 M. Hu, X. Pang and Z. Zhou, J. Power Sources, 2013, 237, 229242.

8 H. Yoon, P. Howlett, A. Best, M. Forsyth and D. MacFarlane, J. Electrochem. Soc., 2013, 160, A1629-A1637.

9 H. Matsumoto, H. Sakaebe, K. Tatsumi, M. Kikuta, E. Ishiko and M. Kono, J. Power Sources, 2006, 160, 1308-1313.

10 S. A. M. Noor, P. C. Howlett, D. R. MacFarlane and M. Forsyth, Electrochim. Acta, 2013, 114, 766-771.

11 G. Girard, M. Hilder, H. Zhu, D. Nucciarone, K. Whitbread, S. Zavorine, M. Moser, M. Forsyth, D. MacFarlane and P. Howlett, Phys. Chem. Chem. Phys., 2015, 17, 8706-8713.

12 V. L. Martins, N. Sanchez-Ramirez, M. C. Ribeiro and R. M. Torresi, Phys. Chem. Chem. Phys., 2015, 17, 23041-23051.

13 M. Hilder, G. Girard, K. Whitbread, S. Zavorine, M. Moser, D. Nucciarone, M. Forsyth, D. MacFarlane and P. Howlett, Electrochim. Acta, 2016, 202, 100-109.

14 M. Forsyth, G. Girard, A. Basile, M. Hilder, D. MacFarlane, F. Chen and P. Howlett, Electrochim. Acta, 2016, 220, 609-617.

15 T. Stephenson, Z. Li, B. Olsen and D. Mitlin, Energy Environ. Sci., 2014, 7, 209-231.

16 Q. Mahmood, M.G. Kim, S. Yun, S.-M. Bak, X.-Q. Yang, H.S. Shin, W.S. Kim, P.V. Braun, H.S. Park, Nano Lett., 15 (2015) 2269-2277.

17 Y. Teng, H. Zhao, Z. Zhang, Z. Li, Q. Xia, Y. Zhang, L. Zhao, X. Du, Z. Du, P. Lv and K. Świerczek, ACS Nano, 2016, 10, 85268535.

18 Y. Chao, R. Jalili, Y. Ge, C. Wang, T. Zheng, K. Shu and G. G. Wallace, Adv. Funct. Mater., 2017, 22, 1700234

19 Y. Ge, C. Wang, Y. Zhao, Y. Liu, Y. Chao, T. Zheng and G. G. Wallace, Small, DOI: 10.1002/smll.201703096, 1703096.

20 S. Zugmann, M. Fleischmann, M. Amereller, R. M. Gschwind, H. Wiemhöfer and H. Gores, Electrochim. Acta, 2011, 56, 3926-3933.

21 E. A. Ponomarev, M. Neumann-Spallart, G. Hodes and C. Lévy-Clément, Thin Solid Films, 1996, 280, 86-89.

22 A. Ambrosi and M. Pumera, ACS Catal., 2016, 6, 3985-3993.

23 M. Hilder, B. Winther-Jensen, D. Li, M. Forsyth and D. R. MacFarlane, Phys. Chem. Chem. Phys., 2011, 13, 9187-9193.

24 V. Stengl and J. Henych, Nanoscale, 2013, 5, 3387-3394.

25 Y. Xia, B. Wang, X. Zhao, G. Wang, H. Wang, Electrochim. Acta, 2016, 187, 55-64.

26 H. Chen, M.B. Müller, K.J. Gilmore, G.G. Wallace, D. Li, Adv Mater., 2008, 20, 3557-3561.

27 T. Weber, J. C. Muijsers and J. W. Niemantsverdriet, J. Phys. Chem., 1995, 99, 9194-9200.

28 X. Fang, X. Yu, S. Liao, Y. Shi, Y.-S. Hu, Z. Wang, G. D. Stucky and L. Chen, Microporous and Mesoporous Mater., 2012, $151,418-423$.

29 M. Ishikawa, T. Sugimoto, M. Kikuta, E. Ishiko and M. Kono, J. Power Sources, 2006, 162, 658-662.

30 Z. Wang, T. Chen, W. Chen, K. Chang, L. Ma, G. Huang, D. Chen and J. Y. Lee, J. Mater. Chem. A, 2013, 1, 2202-2210.

31 X. Zhou, L.-J. Wan and Y.-G. Guo, Chem. Commun., 2013, 49, $1838-1840$. 